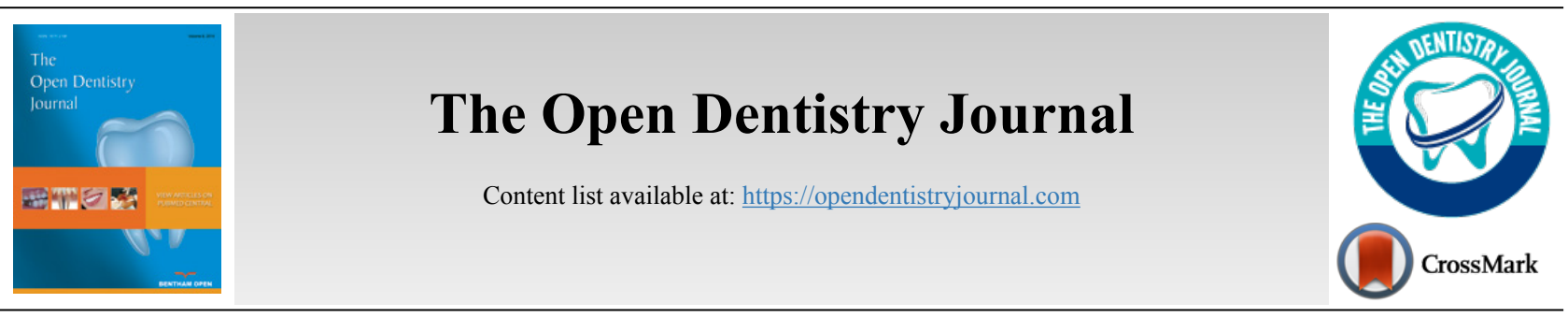

SYSTEMATIC REVIEW

\title{
Significance of Patient Safety and Safety Culture in Dental Schools: A Systematic Review
}

Huda Abutayyem ${ }^{1}$, Lovely $\mathrm{M}^{2}$, Alexander Luke ${ }^{3}$, Yawar Hayat Khan ${ }^{4}$, Muhammad Muhammad ${ }^{5}$ and Biji Thomas George ${ }^{6, *}$

\author{
${ }^{1}$ Department of Orthodontics, Ras al Khaimah College of Dental Sciences, Ras Al-Khaimah, UAE \\ ${ }^{2}$ Department of Prosthodontics, Ras al Khaimah College of Dental Sciences, Ras Al-Khaimah, UAE \\ ${ }^{3}$ Department of Clinical Sciences, College of Dentistry, Ajman University, Ajman, UAE \\ ${ }^{4}$ Department of Dental Materials, Riphah International University, Islamabad, Pakistan \\ ${ }^{5}$ Department of Dental Sciences, Riphah International University Islamabad, Pakistan \\ ${ }^{6}$ Departmnet of Surgery, Ras al Khaimah College of Medical Sciences, UAE
}

\begin{abstract}
:
Objectives:

This article aims to systematically review and analyze the outcome of published literature on patient safety and safety culture related to dental schools. It also aims to observe implemented changes in dental school training and curriculum that have improved patient safety and safety culture within institutions.

Methods:

All studies concerning patient safety and safety culture from the period of January 2010 to May 2020 were included which were specific to dental educational institution settings. The assessment was based on the PRISMA (Preferred Reporting Items for Systematic Reviews and Meta-Analysis) checklist to ascertain that the included studies were specific to the objective of our systematic review.

Results:

The included studies were assessed for country-wise publication, type of study, and its outcome. Of the 10 studies that met the inclusion criteria, 5 articles were related to patient safety. 2 out of the 5 articles were from the United States of America (USA) 2 were from the United Kingdom (UK), followed by 1 from Mexico. For articles related to safety culture, 3 out of the 5 articles were from Saudi Arabia, and 2 were from the USA.

\section{Conclusion:}

The analysis of the selected review articles suggests that rigorous training should be implemented in inpatient record documentation, incident reporting, and infection control protocols. The authors suggested focused training on patient safety culture and the inclusion of safety culture awareness and training to the dental undergraduate curriculum.
\end{abstract}

Keywords: Patient safety, Safety culture, Dentistry, Dental schools, Prevention, Reduction.

\begin{tabular}{l|l|l|l} 
Article History & Received: August 20, 2020 & Revised: February 16, 2021 & Accepted: March 9, 2021
\end{tabular}

\section{INTRODUCTION}

\subsection{Role of Patient Safety and Quality in Dentistry}

Patient safety emphasizes on the prevention and reduction as well as the analysis and reporting of medical errors that may often lead to adverse effects. Approximately 440,000 patients die every year due to hospital errors, injuries, and accidents [1].

\footnotetext{
* Address correspondence to this author at the Associate Professor, Department of Surgery, RAK Medical and Health Sciences University, Al Juwais, Ras al Khaimah, United Arab Emirates; Tel: +971-50-1163495;

E-mail:drbiji@gmail.com
}

In the 1990s multiple reports related to adverse events to patients, were published. The World Health Organization declared that patient safety is an endemic concern, and the World Alliance for Patient Safety was launched in Washington DC on $27^{\text {th }}$ October 2004, in this regard [2]. This initiated quality improvement protocols in the medical field, which were later adopted into dental health care.

In dentistry, Mills, and Batchelor measured quality using the Dental Quality and Outcomes Framework tool and measured clinical effectiveness, safety, and patient experience [3]. These dimensions are validated by data collection and 
evaluation in the form of checklists. The collected data is depicted in various forms, such as fishbone diagram, control chart, stratification, Pareto chart, histogram and scatter diagram, etc. The analyzed data is used as the key performance indicator to analyze the current status regarding patient safety and safety culture within the organization studied. Patient safety in dentistry is defined as control of all possible risk factors, representing the highest-quality dental care with successful outcomes [4].

In dental clinics, much of the patient safety data is evaluated from medical record audits, incident reporting, and the data collection of patient satisfaction. Accurately filled incident report forms identify threats to patient safety and help to formulate guidelines to reduce future patient safety incidents. Many national organizations, such as NPSA (National Patient Safety Agency) in England and Wales, encourage national error reporting. This, in turn, incorporates a patient safety system throughout the country. Yip et al. also observed that medical and dental undergraduates trained in quality accredited institutions in the UK were more aware of adverse drug reporting than students trained outside of UK [5]. Thusu et al. compared patient safety incidents in dentistry to the accuracy of the National Patient Safety Agency Database from January to December 2009. Their data showed that the majority were due to clerical errors $(36 \%)$. The other noted causes were injury sustained during a procedure $(10 \%)$, medical emergency $(6 \%)$, inhalation/ingestion of dental material $(4 \%)$, adverse reactions $(4 \%)$, and wrong-site extraction (2\%) [6]. It was also observed that there was a low reporting of patient safety incidents within the dental specialties, indicating a lack of focus on patient safety culture within the profession. Bedout et al. administered a questionnaire testing dental residents' diagnosis and intervention skills in emergencies in dental practice. They found that hyperventilation was diagnosed incorrectly by $56 \%$ and cardiac arrest by $36 \%$ of the dental residents. Moreover, The authors also stressed the need to do emergency drills and training on a regular basis. [7]

Safety culture is defined by the Health and Safety Commission in the UK as "the product of individual and group values, attitudes, perceptions, competencies, and patterns of behavior that determine the commitment to, and the style and proficiency of an organization's health and safety management. [8] " Ramoni et al. evaluated the safety culture in three US dental schools by a validated Medical Office Survey on Patient Safety Culture (MOSOPS). They analyzed different dimensions, such as organizational learning, teamwork, staff training, work pressure, office process and standardization, leadership role, communication about the error, communication openness, and patient care tracking. He also compared the data between medical practices and dental school practices and concluded that Medical clinics fared much better in safety culture than dental clinics [9]. Al Sweleh et al. conducted a cross-sectional study at the College of Dentistry at King Saud University in Saudi Arabia using a questionnaire validated by the Agency for Healthcare Research and Quality Hospital Survey on Patient Safety Culture (US). They concluded that teamwork within units showed the highest score of $72 \%$, and staffing and non-punitive errors (thatthe errors made by them are not held against them or kept in their file) observed a low score of $10 \%$ [10]. The objective of this review is to search for literature on patient safety culture conducted in dental education institutions and analyze their outcome. The rationale is to observe to what extent dental students and residents are presently aware of patient safety and safety culture and whether they require additional exposure and training during their course. The aim is also to observe implemented changes in dental school training and curriculum that have improved the patient safety and safety culture within institutions. Implementation of training in patient safety and safety culture will ensure that future dentists will inculcate this culture in their practice.

\section{REVIEW METHODOLOGY}

\subsection{Focus Question}

How many dental schools have conducted studies in patient safety and safety culture and published the outcome, and what is their country of origin?

\subsection{Methods}

\subsubsection{Search Strategy and Selection Process}

This review was conducted in line with the Preferred Reporting Items for Systematic Reviews and Meta-Analyses (PRISMA) guidelines. A structured electronic search was conducted of online databases, PubMed, Cochrane Library, and Google Scholar, from January $1^{\text {st, }} 2010$ to 1 st May 2020. The MESH search string used was (("patient safety"[All Fields]) OR ("safety culture"[All Fields])) AND ("dentistry" OR "dental school").

\subsubsection{Total Articles Screened and Selected}

On the initial search of PubMed, Google Scholar, and Cochrane Library databases, 14,360 articles were identified, of which 348 were found not to be related to dentistry based on the title of the articles and hence excluded. Of the remaining 14,012 articles, 355 records were identified from PubMed. Out of the 355 , there were 15 systematic reviews, 124 reviews, 3 classical articles, 17 guidelines, 3 RCTs, 6 meta-analyses, 124 clinical studies along with surveys, 35 clinical trials, and 28 case reports. From Google Scholar, 13,655 articles were identified in the initial search. From the Cochrane Library search, two systematic reviews were obtained. During the abstract screening process, 13,408 studies were either duplicate or were irrelevant to the present study and hence were excluded. From the remaining 604 articles, 518 articles not specific to dental patient safety and safety culture were excluded, and the remaining 86 underwent further scrutiny of the full text by four authors in the second phase. In the final phase, 76 articles related to dental specialties focusing on patient safety or safety culture were excluded as they did not relate to a dental school or dental educational institution. Only 10 studies met the exact inclusion criteria (Fig. 1). A flow chart documenting the article selection process is shown in Fig. (1). Three authors (HA, LM and BG) were involved in the initial selection process; after the initial screening, the excluded titles were rechecked by HA, and LM and both were in 100 percent 
agreement. The final included articles were reviewed by a third and fourth author (YK and $\mathrm{AL}$ ). YK was not in favour of adding case-based studies as they focused more on guidelines for treatment in different fields of dental specialty. Hence after discussion and critical evaluation by all authors as per Prisma checklist, all case-based studies were excluded, and only patient safety and safety culture study related articles conducted within dental institutions were included to prevent bias. The method of screening was followed by Prisma flow chart (Fig. 1).
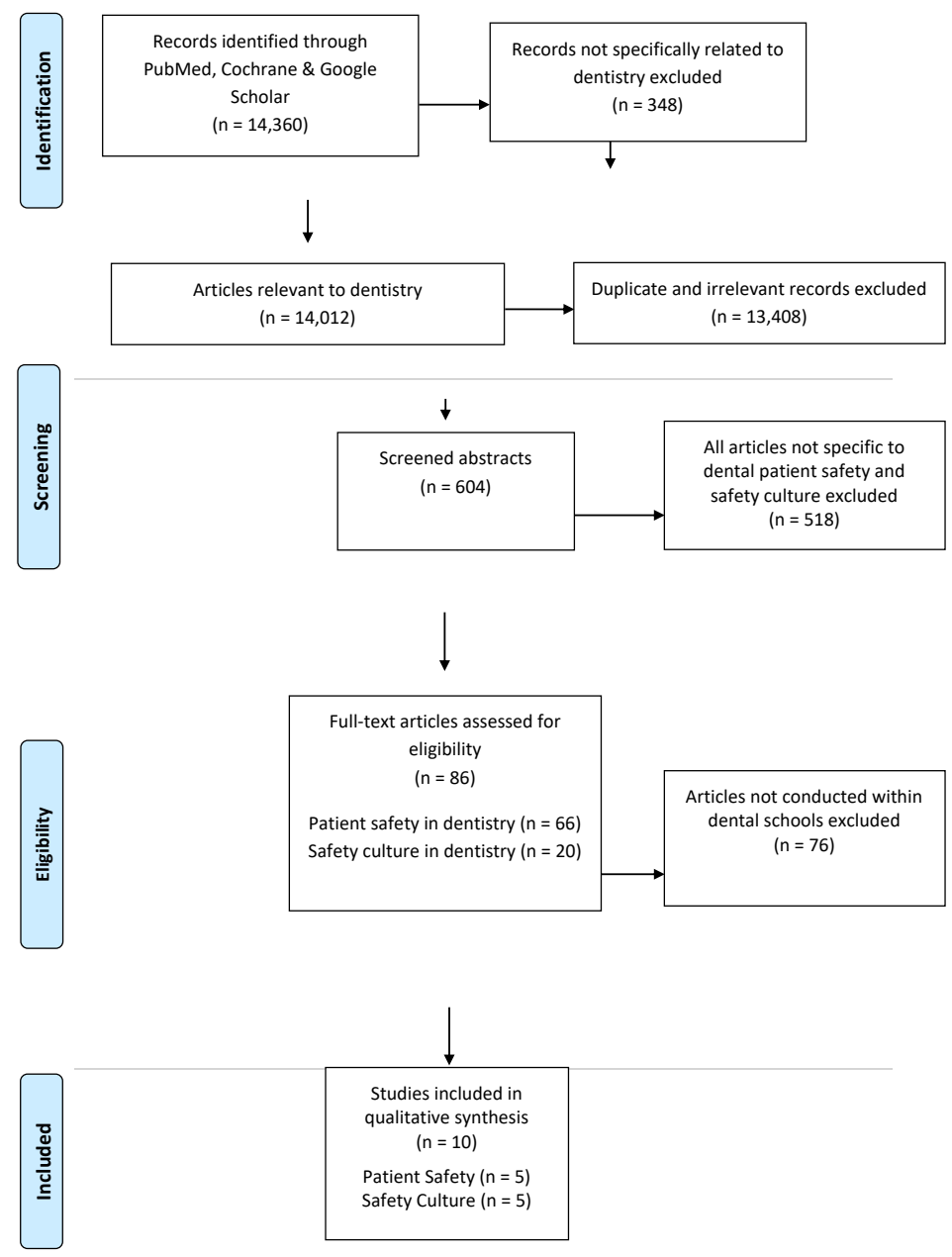

Fig. (1). PRISMA Flow chart.

Table 1. PRISMA Checklist.

\begin{tabular}{|c|c|c|c|}
\hline SECTION/TOPIC & \# & CHECKLIST ITEM & $\begin{array}{l}\text { REPORTED } \\
\text { ON PAGE \# }\end{array}$ \\
\hline Title & 1 & Identify the report as a systematic review, meta-analysis, or both & $\begin{array}{l}\text { Systematic } \\
\text { review }\end{array}$ \\
\hline \multicolumn{4}{|l|}{ ABSTRACT } \\
\hline Structured summary & 2 & $\begin{array}{c}\text { Objectives, data sources, study eligibility criteria, participants, and interventions, study } \\
\text { appraisal and synthesis methods, results, conclusion }\end{array}$ & 1 \\
\hline \multicolumn{4}{|l|}{ INTRODUCTION } \\
\hline Rationale & 3 & Rationale & 5 \\
\hline Objectives & 4 & Focus question & 6 \\
\hline \multicolumn{4}{|l|}{ METHODS } \\
\hline Protocol and registration & 5 & $\begin{array}{l}\text { Indicate if a review protocol exists, if and where it can be accessed (e.g., Web address), and, } \\
\text { if available, provide registration information, including registration number. }\end{array}$ & NA \\
\hline Eligibility criteria & 6 & Inclusion criteria & 6 \\
\hline
\end{tabular}




\begin{tabular}{|c|c|c|c|}
\hline SECTION/TOPIC & $\#$ & CHECKLIST ITEM & $\begin{array}{l}\text { REPORTED } \\
\text { ON PAGE \# }\end{array}$ \\
\hline Information sources & 7 & Databases & 5 \\
\hline Search & 8 & PubMed detailed & 5 \\
\hline Study selection & 9 & PRISMA flow chart attached & Fig: 1 \\
\hline Data collection process & 10 & Methods & 5,6 \\
\hline Data items & 11 & Keywords & 5 \\
\hline Risk of bias in individual studies & 12 & $\begin{array}{c}\text { Describe methods used for assessing the risk of bias of individual studies (including } \\
\text { specification of whether this was done at the study or outcome level) and how this } \\
\text { information is to be used in any data synthesis. }\end{array}$ & NA \\
\hline Summary measures & 13 & Outcome results as table & Table 2 \\
\hline Synthesis of results & 14 & $\begin{array}{l}\text { Describe the methods of handling data and combining results of studies, if done, including } \\
\text { measures of consistency }\left(\text { e.g., } \mathrm{I}^{2}\right) \text { for each meta-analysis. }\end{array}$ & NA \\
\hline Risk of bias across studies & 15 & $\begin{array}{l}\text { Specify any assessment of the risk of bias that may affect the cumulative evidence (e.g., } \\
\text { publication bias, selective reporting within studies). }\end{array}$ & NA \\
\hline Additional analyses & 16 & $\begin{array}{l}\text { Describe methods of additional analyses (e.g., sensitivity or subgroup analyses, meta- } \\
\text { regression), if done, indicating which were pre-specified. }\end{array}$ & NA \\
\hline \multicolumn{4}{|l|}{ RESULTS } \\
\hline Study selection & 17 & $\begin{array}{l}\text { Give numbers of studies screened, assessed for eligibility, and included in the review, with } \\
\text { reasons for exclusions at each stage, ideally with a flow diagram. }\end{array}$ & 6 \\
\hline Study characteristics & 18 & $\begin{array}{l}\text { For each study, present characteristics for which data were extracted (e.g., study size, } \\
\text { PICOS, follow-up period) and provide the citations. }\end{array}$ & 5 \\
\hline Risk of bias within studies & 19 & $\begin{array}{l}\text { Present data on the risk of bias of each study and, if available, any outcome level assessment } \\
\text { (see item 12). }\end{array}$ & NA \\
\hline Results of individual studies & 20 & $\begin{array}{l}\text { For all outcomes considered (benefits or harms), present for each study: (a) simple summary } \\
\text { data for each intervention group, (b) effect estimates and confidence intervals, ideally with a } \\
\text { forest plot. }\end{array}$ & NA \\
\hline Synthesis of results & 21 & $\begin{array}{l}\text { Present results of each meta-analysis done, including confidence intervals and measures of } \\
\text { consistency. }\end{array}$ & NA \\
\hline Risk of bias across studies & 22 & Present results of any assessment of the risk of bias across studies (see Item 15). & NA \\
\hline Additional analysis & 23 & $\begin{array}{l}\text { Give results of additional analyses, if done (e.g., sensitivity or subgroup analyses, meta- } \\
\text { regression [see Item 16]). }\end{array}$ & NA \\
\hline \multicolumn{4}{|l|}{ DISCUSSION } \\
\hline Summary of evidence & 24 & $\begin{array}{l}\text { Summarize the main findings, including the strength of evidence for each main outcome, } \\
\text { consider their relevance to key groups (e.g., healthcare providers, users, and policymakers). }\end{array}$ & 7,8 \\
\hline Limitations & 25 & $\begin{array}{l}\text { Discuss limitations at study and outcome level (e.g., risk of bias) and at review level (e.g., } \\
\text { incomplete retrieval of identified research, reporting bias). }\end{array}$ & 10 \\
\hline Conclusions & 26 & $\begin{array}{l}\text { Provide a general interpretation of the results in the context of other evidence and } \\
\text { implications for future research. }\end{array}$ & 11 \\
\hline \multicolumn{4}{|l|}{ FUNDING } \\
\hline Funding & 27 & $\begin{array}{l}\text { Describe sources of funding for the systematic review and other support (e.g., supply of } \\
\text { data); the role of funders for the systematic review. }\end{array}$ & NA \\
\hline
\end{tabular}

Amongst the ten relevant articles, the maximum publications from the literature review on patient safety were from the USA and UK, and the articles on safety culture were from Saudi Arabia and the USA. The methodological review observed that extensive reviews were conducted until 2010, and no data was available on patient safety in dentistry after that. After 2010, studies related to dental clinics were published as databases, but these extensive dental institutional studies were unavailable except for a few surveys. From 2014 onwards, multiple studies from dental institutions began focusing on orienting and training students and recommended adding patient safety and safety culture within the dental curriculum. They also stressed that patient safety principles are to be included in national rules, regulations, and guidelines as policies.

\subsection{Inclusion Criteria}

All articles in English and specific to patient safety in dentistry and safety culture in dental institutions were included. All peer-reviewed and published reviews, and observational and cross-sectional studies were included.

\subsection{Exclusion Criteria}

All articles published in languages other than English were excluded. All articles not specifically related to patient safety and safety culture in dental schools were excluded. All case studies, guidelines, editorials, letters, conference abstracts, books, theses, and opinions were excluded. All articles on patient care interventions without reference to patient safety and safety culture were excluded. 
Table 2. Short-listed studies related to patient safety and safety culture.

\begin{tabular}{|c|c|c|c|c|c|}
\hline References & Country & $\begin{array}{c}\text { Participants/articles } \\
\text { (N) }\end{array}$ & $\begin{array}{l}\text { Time } \\
\text { period }\end{array}$ & Type/Method of study & $\begin{array}{l}\text { Selected Outcome } \\
\text { Suggestions to improve patient } \\
\text { safety/culture (bullet, in bold) }\end{array}$ \\
\hline Kiersma et al. (2011) [11] & UK & $\begin{array}{l}23 \text { articles } \\
\text { Medicine: } 13 \\
\text { Nursing: } 4 \\
\text { Pharmacy: } 3 \\
\text { Dentistry: } 0\end{array}$ & $\begin{array}{l}1966 \\
-2010\end{array}$ & \begin{tabular}{|l|} 
A systematic review \\
(Patient safety \\
instruction in health \\
professional curriculum)
\end{tabular} & $\begin{array}{l}\text { 1. 1966-2010: No articles found on patient } \\
\text { safety initiative in dentistry } \\
\text { 2. Patient safety training was added to the } \\
\text { medical curriculum in the form of lectures, } \\
\text { case-based exercises, active and simulation } \\
\text { exercises, along with medical audits. } \\
\text { 3. Self-assessment survey was used to } \\
\text { determine student perception of patient safety } \\
\text { after training them. The assessments from } \\
\text { various literature review show improvement } \\
\text { in knowledge, attitude, and skill related to } \\
\text { patient safety } \\
\text { - Recommend curriculum change to } \\
\text { include patient safety. The above } \\
\text { assessment showed improvement in } \\
\text { patient safety, and hence the authors } \\
\text { recommended curriculum change to } \\
\text { include patient safety. }\end{array}$ \\
\hline Pemberton et al. 2014 [14] & UK & $\begin{array}{l}16 \text { dental institutes under } \\
\text { NHS }\end{array}$ & $\begin{array}{l}\text { Dec } \\
2009- \\
\text { Sept } \\
2013\end{array}$ & $\begin{array}{l}\text { Measuring patient safety } \\
\text { through the development } \\
\text { of a dental clinical } \\
\text { effectiveness dashboard } \\
\text { for institutions }\end{array}$ & $\begin{array}{l}\text { The dashboard contained: } \\
\text { 1. Measures of harm evaluated by the number } \\
\text { of patient falls, medication errors, and } \\
\text { adverse events. } \\
\text { 2. Measures of reliability of safety processes, } \\
\text { such as hand hygiene, dental audits, clinical } \\
\text { training, correct site surgery, patient } \\
\text { identification, progress note entries, } \\
\text { completed consent form, BLS, and ACLS } \\
\text { training with the annual report. } \\
\text { 3. Clinical effectiveness. All these were } \\
\text { monitored over three years to improve patient } \\
\text { safety. The dashboard had performance } \\
\text { indicators on patient safety. When the } \\
\text { indicator was red, it showed a fall in the set } \\
\text { benchmark, and hence initiatives were taken } \\
\text { to work on the identified factor. This way, in } \\
\text { three years, almost all factors were showing a } \\
\text { green indicator, indicating an acceptable } \\
\text { benchmark for all patient safety factors. } \\
\text { - Recommend consistent training in } \\
\text { patient safety protocols to increase patient } \\
\text { safety compliance. }\end{array}$ \\
\hline Thierer et al. (2017) [13] & USA & 1 dental school & $\begin{array}{l}2014 \\
-2015\end{array}$ & $\begin{array}{l}\text { A retrospective review } \\
\text { of Electronic } \\
\text { documentation in US } \\
\text { dental school by students }\end{array}$ & $\begin{array}{l}\text { 1. On the evaluation of progress notes, poorly } \\
\text { documented records were identified, and the } \\
\text { students who did poor documentation were } \\
\text { traced. } \\
\text { 2. The students who did poor documentation } \\
\text { and their supervising faculty were given } \\
\text { corrective training in documentation } \\
\text { - Recommend repeated monitoring } \\
\text { followed by corrective training for proper } \\
\text { documentation improved compliance. }\end{array}$ \\
\hline $\begin{array}{l}\text { Osegueda- Espinosa et al. } \\
(2017)[12]\end{array}$ & Mexico & $\begin{array}{l}34 \text { Dental school } \\
\text { graduates }\end{array}$ & $\begin{array}{l}2013- \\
2014\end{array}$ & $\begin{array}{l}\text { Self-administered } \\
\text { questionnaire survey }\end{array}$ & $\begin{array}{l}\text { During undergraduate dental clinical training, } \\
\text { dental students committed errors that placed } \\
\text { patients at risks, such as pulp exposure, sharp } \\
\text { instrument injury, burns, wrong tooth } \\
\text { extraction, injection of sodium hypochlorite } \\
\text { instead of local anesthesia, breakage of } \\
\text { needles during anesthesia, and accidental } \\
\text { swallowing of a restoration } \\
\text { - Recommend more training, } \\
\text { orientation, and continuing education in } \\
\text { patient safety protocols. }\end{array}$ \\
\hline
\end{tabular}




\begin{tabular}{|c|c|c|c|c|c|}
\hline References & Country & $\begin{array}{c}\text { Participants/articles } \\
\text { (N) }\end{array}$ & $\begin{array}{l}\text { Time } \\
\text { period }\end{array}$ & Type/Method of study & $\begin{array}{l}\text { Selected Outcome } \\
\text { Suggestions to improve patient } \\
\text { safety/culture (bullet, in bold) }\end{array}$ \\
\hline Bedout et al. (2018) [18] & USA & $\begin{array}{l}22 \text { residents in specialty } \\
\text { programs, } 21 \text { specialist } \\
\text { faculty members, and } 24 \\
\text { general practice faculty } \\
\text { members and others }\end{array}$ & 2017 & Exploratory study & $\begin{array}{l}\text { Dental residents were given a questionnaire } \\
\text { with ten clinical emergency cases and asked } \\
\text { to identify the diagnosis and indicated } \\
\text { intervention. } \\
\text { Several responses had varying degrees of } \\
\text { incorrect diagnoses and management across } \\
\text { all groups. In the case of hyperventilation, } \\
59 \% \text { of responses had an incorrect diagnosis } \\
\text { in the case of cardiac arrest, } 36 \% \text { had } \\
\text { incorrect diagnoses. } \\
\text { - Repetitive training to be done for } \\
\text { better preparedness in the diagnosis and } \\
\text { management of medical emergencies in a } \\
\text { dental setting. }\end{array}$ \\
\hline Ramoni et al. 2014 [19] & USA & $\begin{array}{l}3 \text { dental schools with } \\
328 \text { participants; dental } \\
\text { students: } 48 \% \text {, Dental } \\
\text { hygienists: } 1 \% \\
\text { Faculty: } 23 \% \text { and staff: } \\
25 \%\end{array}$ & $\begin{array}{l}2010- \\
2011\end{array}$ & $\begin{array}{l}\text { Medical office survey on } \\
\text { patient safety culture } \\
\text { (AHRQ) }\end{array}$ & $\begin{array}{l}\text { 1. Six dimensions were evaluated: } \\
\text { Communication Openness, Communications } \\
\text { about Error, Organizational Learning, } \\
\text { Overall Perceptions of Patient Safety and } \\
\text { Quality, Owner/Managing } \\
\text { Partner/Leadership Support for Patient } \\
\text { Safety, and Teamwork. } \\
\text { 2. Compared Data with an average of } \\
\text { medical fields from MOSOPS } \\
\text { 3. Patient follow up for dental fields was only } \\
36 \% \text {, but for medical fields, the patient } \\
\text { follow up was } 82 \% \\
\text { - Recommendation: A clear need is } \\
\text { demonstrated to improve dental patient } \\
\text { safety culture in dental institutions. }\end{array}$ \\
\hline Al Sweleh et al. 2017 [10] & $\begin{array}{l}\text { Saudi } \\
\text { Arabia }\end{array}$ & $\begin{array}{l}1 \text { Dental school } \\
\text { Participants: } \\
\text { Interns } \\
\text { Dental students } \\
\text { Practitioners } \\
\text { Dental assistants }\end{array}$ & $\begin{array}{l}2017 \\
-2018\end{array}$ & $\begin{array}{l}\text { Cross-sectional study } \\
\text { based questionnaire } \\
\text { (Modified AHRQ) }\end{array}$ & $\begin{array}{l}\text { Twelve dimensions were evaluated: } \\
\text { Teamwork, manager expectations, } \\
\text { organizational learning, management support, } \\
\text { the overall perception of patient safety, } \\
\text { communication, adverse event reporting, } \\
\text { handoffs, blame culture, openness, and } \\
\text { staffing. } \\
\text { Perception of patient safety culture varied } \\
\text { among students to practitioners. } \\
\text { • Improvement in communication } \\
\text { openness, staffing, and fear of blame is } \\
\text { required in dental clinics. }\end{array}$ \\
\hline Al- Surimi et al. 2018 [17] & $\begin{array}{l}\text { Saudi } \\
\text { Arabia }\end{array}$ & $\begin{array}{l}2 \text { Dental schools } \\
\text { Participants: } \\
\text { Only female dental } \\
\text { students: } 133 \text { and dental } \\
\text { hygienists: } 88\end{array}$ & $\begin{array}{l}\text { Nov } \\
2016- \\
\text { Jan } \\
2017\end{array}$ & $\begin{array}{l}\text { A cross-sectional study } \\
\text { based on a self- } \\
\text { administrative survey }\end{array}$ & $\begin{array}{l}\text { Student perceptions on teamwork, safety } \\
\text { climate, job satisfaction, stress recognition, } \\
\text { management support, and working conditions } \\
\text { were evaluated. The overall average outcome } \\
\text { indicated } 54.4 \% \text { for teamwork, } 51.4 \% \text { for } \\
\text { safety climate, } 64.5 \% \text { for job satisfaction, } \\
56.2 \% \text { for stress recognition, } 50.7 \% \text { for } \\
\text { management support, and } 55.3 \% \text { for working } \\
\text { condition. } \\
\text { - Patient safety principles are to be } \\
\text { included in national rules, regulations, and } \\
\text { guidelines. Increased awareness and } \\
\text { training students will improve the patient } \\
\text { safety culture. }\end{array}$ \\
\hline Ahsan et al. 2019 [15] & $\begin{array}{l}\text { Saudi } \\
\text { Arabia }\end{array}$ & $\begin{array}{l}\text { Dental schools: } 2 \text { clinics } \\
\text { of dental schools } \\
\text { Dental staff and assistants } \\
\text { including residents: } 149\end{array}$ & $\begin{array}{l}\text { March } \\
\text { to June } \\
2016\end{array}$ & $\begin{array}{l}\text { A cross-sectional study } \\
\text { based on Patient safety } \\
\text { culture hospital } \\
\text { Questionnaire. }\end{array}$ & $\begin{array}{l}\text { Teamwork, adverse event reporting, } \\
\text { supervisor appreciation when a job was done } \\
\text { well, and importance to patient safety was } \\
\text { evaluated. } \\
\text { Variation in the perception of patient safety } \\
\text { culture in the same organization and between } \\
\text { organizations. } \\
\text { - Recommend that respective } \\
\text { organizations give priority to patient } \\
\text { safety }\end{array}$ \\
\hline
\end{tabular}


(Table $\square$ ) contd.....

\begin{tabular}{|c|c|c|c|c|c|}
\hline References & Country & $\begin{array}{c}\text { Participants/articles } \\
\text { (N) }\end{array}$ & $\begin{array}{l}\text { Time } \\
\text { period }\end{array}$ & Type/Method of study & $\begin{array}{l}\text { Selected Outcome } \\
\text { Suggestions to improve patient } \\
\text { safety/culture (bullet, in bold) }\end{array}$ \\
\hline Yansane et al. 2020 [16] & USA & $\begin{array}{l}3 \text { US Dental schools; } 656 \\
\text { participants, including } \\
\text { students, staff, and } \\
\text { assistants }\end{array}$ & 2016 & $\begin{array}{l}\text { Cross-sectional study } \\
\text { (Medical office survey } \\
\text { on patient safety culture) }\end{array}$ & $\begin{array}{l}\text { Ten dimensions were evaluated: overall } \\
\text { perceptions of patient safety and quality, } \\
\text { organizational learning, teamwork, staff } \\
\text { training, work pressure, communication } \\
\text { openness, communications about the error, } \\
\text { owner/managing partner/leadership support } \\
\text { for patient safety, patient follow-up and } \\
\text { office processes. } \\
\text { The analyzed dental data were compared } \\
\text { with previously published medical data, and } \\
\text { it was found that medical schools } \\
\text { outperformed dental schools in overall } \\
\text { quality dimensions in } 2012 \text {, but in } 2016 \text { after } \\
\text { training, the gap in performance between } \\
\text { medical and dental fields had narrowed. } \\
\text { The survey was first conducted in } 3 \text { dental } \\
\text { schools in } 2012 . \text { After focused improvement } \\
\text { training, the survey was repeated in the same } \\
\text { dental schools in } 2016 \text {. The second survey } \\
\text { showed an improvement in performance from } \\
2012 \text { to } 2016 \text {. } \\
\text { • Recommend focused training of all } \\
\text { dental providers on patient safety culture. }\end{array}$ \\
\hline
\end{tabular}

\section{RESULTS}

Articles were screened and finalized as per the PRISMA checklist (Table 1) for systematic review. The method for screening was done as depicted by the PRISMA flow chart (Fig. 1). Articles related to the field of medicine, pharmacy, nursing, articles specific to pediatric dentistry, oral surgery though indirectly related to patient safety and safety culture, were excluded. The initial screening was done by two authors, and 86 full-text articles were short-listed. From the short-listed articles, 66 were related to patient safety in dentistry and 20 to safety culture in the dental field. Four authors, after reading through the full-text articles as per the exclusion criteria, eliminated 76 articles which either were related to dental specialties or were not related to a dental school or dental educational institution. Only 10 studies met the exact inclusion criteria. Of the 10 articles, 5 were related to patient safety and 5 were related to safety culture (Table 2).

Table (2) presents all the included articles in this review along with the outcomes of each study and recommendations from the authors on how patient safety and safety culture can be improved in dental schools. In our review, we observed that the maximum publications from the literature review on patient safety were from the USA and UK, and the articles on safety culture were from Saudi Arabia and the USA. Kiersma et al. in 2011, did a systematic review of curriculum change incorporating patient safety. The authors extensively reviewed 6 databases from 1966 - 2010 and found no reviews related to patient safety in dentistry [11]. They highlighted the fact that the medicine, nursing, and pharmacy fields had published studies and reviews regarding patient safety curriculum. They also pointed out that medicine, nursing and pharmacy have published data that training on patient safety was imparted in the form of lectures, case-based exercises, active and simulation exercises, along with medical audits. These forms of training were added to the existing curriculum for medical, nursing, and pharmacy. From 2014 onwards, multiple studies from dental institutions began focusing on orienting and training students $[12,13,14]$. All the five reviewed articles (Table 2) recommended more training and orientation, and continuing education in patient safety protocols. Theirer, in, followed up students' progress notes and documented them. Students who continually performed poorly in the documentation of medical records in the dental clinic were retrained and re-evaluated for their documentation skills [13]. The authors stated that enforcing repeated monitoring followed by training for proper documentation improved compliance. Pemberton et al. maintained a dashboard for all patient safety factors in dental institutions [14]. This clinical effectiveness dashboard had three color codes, red indicated compliance below the benchmark, amber indicated borderline compliance, and green indicated good compliance to patient safety factors. The quality department kept a tab of those factors which had red indicators and focused on improving those factors below the benchmark. Over a period of time, the red indicators turned green, indicating compliance. Hence the authors observed that maintaining a clinical effectiveness dashboard can improve patient safety practices within an organization.

The results about safety culture indicated that awareness in dental schools regarding safety culture is improving over the last few years but compared to medicine, the progress is slow. All studies on safety culture were survey-based cross-sectional studies $[9,10,15,16,17]$. The authors recommended focused training of all students and staff on patient safety culture. They also stressed that patient safety principles are to be included in national rules, regulations, and guidelines. Also, increased awareness and training of students will improve the patient safety culture. No systematic review has been published exclusively for patient safety and safety culture in dentistry and dental institutions. The summary of all the reviewed study results is highlighted in Table (2). 


\section{DISCUSSION}

The concept of patient safety in dentistry was initiated due to multiple reported adverse events in the media, of which one example was in the UK when a newspaper reported a 17-yearold girl's death during wisdom tooth removal in 2011 [18]. Many authors, thereafter, such as Kalenderian et al. in 2017, reviewed adverse event data and classified dental adverse events into those that result in temporary, moderate, and severe harm to the patient [19]. Obadan et al. searched published literature from 1970 to June 2013 on patient harm and found 182 publications (containing 270 cases). They observed that the commonest problems were delayed treatment, unnecessary treatment, or misdiagnosis. Of the reviewed cases, $24.4 \%$ of the patients had permanent harm, and $11.1 \%$ of the patients died [20]. Hiivala et al. retrospectively evaluated data collected from the Finnish Patient Insurance Centre (FPIC) for claims. They found that the most common complaints were related to endodontics, prosthetics, and oral surgical procedures [21].

The American Association of Medical Colleges has recommended the addition of education regarding quality improvement in the undergraduate curriculum [22]. In dental colleges, multiple survey-based cross-sectional studies have been carried out by various authors on patient safety culture $[23,24,25]$. The commonest survey tool used to measure patient safety culture is the Agency for Healthcare Research and Quality Patient Safety Culture [26]. They included dimensions, such as just culture (an environment where individuals feel free to report errors and help the organization to learn from mistakes), reporting culture, learning culture, leadership, risk analysis, work-load management, sharing learning, and resource management.

Many authors, after conducting cross-sectional studies in dental schools, have suggested that meticulous training and orientation in guidelines and protocols along with the addition of patient safety as part of the undergraduate dental curriculum would improve patient safety and safety culture perceptions in the dental field $[15,16,17]$. Even though the urgent need to emphasize patient safety measures through the dental curriculum has been suggested by authors, this is being confined to suggestions and is not yet practically implemented in most dental institutions. WHO, in 2011, formulated a multiprofessional patient safety curriculum for the implementation in medical, educational institutions [27]. It has two parts: Part A consisting of a teacher's guide on imparting knowledge about patient safety to educators, and Part B with ready to teach topics on patient safety. In 2012, they conducted a global evaluation study to evaluate the outcome of this policy in dental educational institutions. The selected dental schools/universities were from Europe, Africa, and the PanAmerican and southeast Asian regions. In 2013, the evaluation results were analyzed with pre and post-teaching surveys. The analyzed data, as indicated by the pre-teaching survey, showed that the educators were not sufficiently aware of patient safety and hence were not able to guide students effectively. The post teaching survey showed that, following training, awareness, knowledge, and clinical implementation of patient safety culture improved among students and staff in the same way within the organization. They also concluded that after implementing the pilot patient safety curriculum, the overall patient safety practices within the organization improved tremendously. The limitation of this review is that only one global pilot study exists from WHO on patient safety after the implementation of patient safety and safety culture as part of the curriculum in dental schools.

\section{CONCLUSION}

During the abstract screening, it was observed that published literature was by far larger for the field of medicine than dentistry. This, in turn, might be the reason that adherence to patient safety and safety culture protocols are found to be higher in the field of medicine than in dentistry. Authors have highlighted that, to improve patient safety and safety culture, these concepts should be included in the undergraduate dental curriculum. It is observed from our review that only 10 studies were published from dental educational institutions. The paucity of published literature from dental educational institutions indicates a need to revise the existing dental undergraduate curriculum and inculcate a safety culture among undergraduate dental students. From the literature, the commonest observed problems were delayed treatment, unnecessary treatment, or misdiagnosis. The WHO multiprofessional patient safety curriculum, if implemented in all dental teaching institutions worldwide, can improve patient safety practices, as proved through this study. This, in turn, would lead to a foundation for patient safety culture measures being initiated in dental educational institutions. Whether dental educational institutions incorporate safety and safety culture in their organizations and curriculum should be considered when ranking such institutions. This will encourage the administrations of these institutions to initiate the process of implementing patient safety and safety culture practices within the organization.

\section{CONSENT FOR PUBLICATION}

Not applicable.

\section{FUNDING}

None.

\section{CONFLICT OF INTEREST}

The authors declare no conflict of interest, financial or otherwise.

\section{ACKNOWLEDGEMENTS}

Declared none.

\section{REFERENCES}

[1] Kohn L, Corrigan J, Donaldson M, Linda T, Linda T, Kohn, Janet M. Corrigan and MSD, Hendee WR. To Err Is Human Building a Safer Health System 2001; 6

[2] WHO. World Alliance for Patient Safety. WHO Available from http://www. who.int/patientsafety/worldalliance/en/

[3] Mills I, Batchelor P. Quality indicators: The rationale behind their use in NHS dentistry. Br Dent J 2011; 211(1): 11-5. [http://dx.doi.org/10.1038/sj.bdj.2011.521] [PMID: 21738180]

[4] Quality Alliance D.. Quality Measurement in Dentistry A Guidebook Dental Quality Alliance 2019. Available from www.ada.org/dqa

[5] Yip J, Radford DR, Brown D. How do UK dentists deal with adverse 
drug reaction reporting?British Dental Journal. Nature Publishing Group 2013; Vol. 214: pp. E22-2.

[http://dx.doi.org/10.1038/sj.bdj.2013.426]

[6] Thusu S, Panesar S, Bedi R. Patient safety in dentistry - state of play as revealed by a national database of errors. Br Dent J 2012; 213(3)E3 [http://dx.doi.org/10.1038/sj.bdj.2012.669] [PMID: 22878337]

[7] de Bedout T, Kramer K, Blanchard S, et al. Assessing the Medical Emergency Preparedness of Dental Faculty, Residents, and Practicing Periodontists: An Exploratory Study. J Dent Educ 2018; 82(5): 492-500.

[http://dx.doi.org/10.21815/JDE.018.058] [PMID: 29717073]

[8] Cooper MD. Towards a model of safety culture Available from www.elsevier.com/locate/ssci

[http://dx.doi.org/10.1016/S0925-7535(00)00035-7]

[9] Ramoni R, Walji MF, Tavares A, et al. Open wide: Looking into the safety culture of dental school clinics. J Dent Educ 2014; 78(5): 745-56.

[http://dx.doi.org/10.1002/j.0022-0337.2014.78.5.tb05726.x] [PMID: 24789834]

[10] Al Sweleh FS, Al Saedan AM, Al Dayel OA. Patient safety culture perceptions in the college of dentistry. Medicine (Baltimore) 2018; 97(2)e9570

[http://dx.doi.org/10.1097/MD.0000000000009570] [PMID: 29480849]

[11] Kiersma ME, Plake KS, Darbishire PL. Patient safety instruction in US health professions education. Am J Pharm Educ 2011; 75(8): 162. [http://dx.doi.org/10.5688/ajpe758162] [PMID: 22102752]

[12] Osegueda-Espinosa A. LS-P-J of patient, 2017 undefined Dentists survey on adverse events during their clinical training 2017. Available from https://europepmc.org/article/med/29112027

[13] Thierer TE, Delander KA. Improving Documentation, Compliance, and Approvals in an Electronic Dental Record at a U.S. Dental School. J Dent Educ 2017; 81(4): 442-9. [http://dx.doi.org/10.21815/JDE.016.004] [PMID: 28365609]

[14] Pemberton MN, Ashley MP, Shaw A, Dickson S, Saksena A. Measuring patient safety in a UK dental hospital: Development of a dental clinical effectiveness dashboard. Br Dent J 2014; 217(7): 375-8. [http://dx.doi.org/10.1038/sj.bdj.2014.859] [PMID: 25303591]

[15] Ahsan SH, Abdul Wahid AQ, Alali S, et al. A comparison of patient safety culture at two campuses of Riyadh based dental College. J Pak Med Assoc 2019; 69(1): 72-6. https://pubmed.ncbi.nlm.nih.gov/3062 $3916 /$
[PMID: 30623916]

[16] Yansane A, Lee JH, Hebballi N, et al. Assessing the Patient Safety Culture in Dentistry. JDR Clin Trans1 Res 2020 [http://dx.doi.org/10.1177/2380084419897614]

[17] Al-Surimi K, AlAyadi H, Salam M. Female dental students' perceptions of patient safety culture: A cross sectional study at a middle eastern setting. BMC Med Educ 2018; 18(1): 301. [http://dx.doi.org/10.1186/s12909-018-1415-8] [PMID: 30526570]

[18] Maryland teen Jenny Olenick, 17, dies after wisdom teeth surgery | Daily Mail Online Available from https://www.dailymail.co.uk/ news/article-2074641/Maryland-teen-Jenny-Olenick-17-dies-wisdomteeth-surgery.html

[19] Kalenderian E, Obadan-Udoh E, Maramaldi P, et al. Classifying Adverse Events in the Dental Office. J Patient Saf 2017. [http://dx.doi.org/10.1097/PTS.0000000000000407] 28671915]

[PMID:

[20] Obadan EM, Ramoni RB, Kalenderian E. Lessons learned from dental patient safety case reports. J Am Dent Assoc 2015; 146(5): 318-26.e2. [http://dx.doi.org/10.1016/j.adaj.2015.01.003] [PMID: 25925524]

[21] Hiivala N, Mussalo-Rauhamaa H, Murtomaa H. Can patients detect hazardous dental practice? A patient complaint study. Int J Health Care Qual Assur 2015; 28(3): 274-87.

[http://dx.doi.org/10.1108/IJHCQA-05-2014-0052] [PMID: 25860924]

[22] Association of American Medical colleges. Contemporary Issues in Medicine: Quality of Care Medical School Objectives Project. 2001.

[23] Managing Maintenance Error. A Practical Guide: Reason, James, Hobbs, Alan Available from https://www.amazon.com/ManagingMaintenance-Error-Practical-Guide/dp/075461591X

[24] Fleming M, Wentzell N. Patient safety culture improvement tool: Development and guidelines for use. Healthc Q 2008; 11(3): 10-5. [http://dx.doi.org/10.12927/hcq.2013.19604]

[25] Ashcroft DM, Morecroft C, Parker D, Noyce PR. Safety culture assessment in community pharmacy: Development, face validity, and feasibility of the Manchester Patient Safety Assessment Framework. Qual Saf Health Care 2005; 14(6): 417-21.

[http://dx.doi.org/10.1136/qshc.2005.014332] [PMID: 16326787]

[26] Farquhar M. AHRQ Quality Indicators 2008. Available from Agency for Healthcare Research and Quality http://www.ncbi.nlm.nih.gov /pubmed/21328764

[27] WHO. WHO Multi-Professional Patient Safety Curriculum Guide 2019. Available from World Health Organizationhttp://www.who. int/patientsafety/education/mp_curriculum_guide/en/

\section{(C) 2021 Abutayyem et al.}

This is an open access article distributed under the terms of the Creative Commons Attribution 4.0 International Public License (CC-BY 4.0), a copy of which is available at: https://creativecommons.org/licenses/by/4.0/legalcode. This license permits unrestricted use, distribution, and reproduction in any medium, provided the original author and source are credited. 